\title{
IMPLEMENTASI GLOBAL POSITION SYSTEM (GPS) DAN PETA DIGITAL PADA APLIKASI MANDOSE UNTUK PENCARIAN PERANGKAT MOBILE
}

\author{
Ahmad Andi Ilhamway Nediansyah ${ }^{1)}$, Adi Sucipto ${ }^{2)}$ \\ ${ }^{1}$ Program Studi Informatika, ${ }^{2}$ Program Studi Teknologi Informasi \\ Fakultas Teknik dan ilmu Komputer Universitas Teknokrat Indonesia \\ Jl. H.ZA Pagaralam, No 9-11, Labuhanratu,Bandarlampung \\ Email:' ${ }^{1}$ lhamdroid02@gmail.com, ${ }^{2}$ adi.sucipto@teknokrat.ac.id
}

\begin{abstract}
This research is conducted on the basis of problems that often occur in college, namely the difficulty of students in finding or meeting college teacher. Different class schedules and busy college teacher make students choose to wait, many students who have long waited but not visit the college teacher, so wasted time and do not finish the existing affairs. Seeing these conditions the author will try to design and build an application that can monitor or track the presence of college teacher. Mobile now has a variety of features with the support of the latest technology that can facilitate the community. To make it easier to know the position and presence of someone, now this can be done through the phone. Therefore, the author will discuss about making MANDOSE application, MANDOSE is a native application that runs on mobile phone with android operating system support, utilizing A-GPS technology and Google Maps. This application is client-server based where client application is built using android programming language, while the backend server side is built using PHP programming language and MySQL database. Data in the form of location coordinates and lecturer information obtained on the client side (college teacher) will be sent into the database on the server side, then will be sent back to the client side (student) which is then displayed in digital map form. Application passes in functional black box test using equivalence partitioning method, function can run $100 \%$ with minimum operating system version android 5.0 (Lollipop). The application passes ISO 9126 standard quality test with reliability aspect (89.3\%), usability (90\%), efficiency (87.3\%) aspect, and portability aspect of application can run optimally in various device and pass in GPS accuracy test with result the resulting coordinates approximate the expected coordinates.
\end{abstract}

Keyword: Mandose, client-server, mobile, tracking, GPS.

\begin{abstract}
Abstrak
Penelitian ini dilakukan atas dasar masalah yang sering terjadi dikampus atau perguruan tinggi, yaitu sulitnya mahasiswa dalam mengetahui lokasi dosen. Jadwal kelas yang berbeda serta sibuknya dosen membuat mahasiswa memilih menunggu, banyak mahasiswa yang sudah lama menunggu tetapi tidak kunjung dapat menemui dosen, sehingga terbuangnya waktu dan tidak selesainya urusan yang ada. Melihat kondisi tersebut peneliti akan mencoba untuk merancang dan membangun sebuah aplikasi yang dapat memantau atau melacak keberadaan dosen. Handphone saat ini memiliki berbagai macam fitur dengan dukungan teknologi terkini yang dapat memudahkan masyarakat. Untuk mempermudah mengetahui posisi dan keberadaan seseorang, sekarang ini dapat dilakukan melalui handphone. Oleh sebab itu peneliti akan membahas tentang pembuatan aplikasi MANDOSE, MANDOSE merupakan sebuah aplikasi native yang dijalankan di handphone dengan dukungan operating sistem android, memanfaatkan teknologi A-GPS serta Google Maps. Aplikasi ini berbasis client-server dimana aplikasi client dibangun menggunakan bahasa pemrograman android, sedangkan sisi backend server dibangun menggunakan bahasa pemrograman PHP dan database MySQL. Data berupa koordinat lokasi dan infromasi dosen yang didapat pada sisi client (dosen) akan dikirimkan ke dalam database pada sisi server, kemudian akan dikirm kembali ke-sisi client (mahasiswa) yang selanjutnya ditampilkan dalam bentuk map digital. Aplikasi lolos dalam uji fungsional blackbox dengan menggunakan metode equivalence partitioning, fungsi dapat berjalan 100\% dengan minimal versi operating sistem android 5.0 (Lollipop). Aplikasi lolos dalam uji kualitas standar ISO 9126 dengan nilai aspek reliability (89.3\%), aspek usability $(90 \%)$, aspek efficiency $(87.3 \%)$, dan aspek portability aplikasi dapat berjalan secara optimal diberbagai macam perangkat serta lolos dalam uji keakuratan GPS dengan hasil koordinat yang dihasilkan mendekati koordinat yang diharapkan.
\end{abstract}

Kata Kunci: Mandose, client-server, mobile, tracking, GPS.

\section{Pendahuluan}

Perkembangan teknologi komputer saat ini mengalami kemajuan dengan cepat, seiring berkembangnya teknologi perangkat keras (hardware) pengendalian tampilan, yang dimanfaatkan untuk menyampaikan informasi dan pengetahuan dalam bentuk visual. Masyarakat pada umumnya sangat membutuhkan alat untuk berkomunikasi 
yang dapat dibawa kemanapun, sehingga menunjang dan memudahkan dalam menjalani kegiatan sehari-hari. Setiap mahasiswa di perguruan tinggi, erat kaitanya dengan dosen sebagai pengajar serta pembimbing di dalam kampus. Urusan tugas, ulangan, quis, tanda tangan, proposal, dan penelitian, semuanya berurusan dengan dosen. Jadwal dosen yang padat, serta terkadang beberapa yang tidak ingin ditemui, membuat mahasiswa kesulitan untuk bertemu dosen yang bersangkutan, sehingga mahasiswa memilih untuk menunggu. Banyak mahasiswa yang sudah lama menunggu akan tetapi tidak bertemu dengan dosen, hal ini tentu tidak efektif, karena waktu yang terbuang untuk menunggu, serta tidak terselesaikanya urusan yang ada.

Beberapa tahun terakhir ini tengah marak perangkat bergerak atau mobile device, salah satu perangkat mobile yang paling pesat adalah smartphone. Dalam situs gs.statcounter.com pada tahun 2016 sampai 2017, saat ini di seluruh dunia tercatat pengguna perangkat mobile smartphone aktif sekitar $51.79 \%$ dan khususnya untuk indonesia tercatat sekitar $73.82 \%$ angka yang cukup besar membuktikan bahwa hampir setiap orang memiliki perangkat mobile smartphone. Hal ini tidak lepas dari adanya sistem operasi, di Indonesia tercatat pengguna sistem operasi android mencapai $79.98 \%$, sangat besar jika dibandingkan dengan pengguna IOS yang hanya $3.61 \%$ dan BlackBerry $1.42 \%$. Teknologi telekomunikasi merupakan salah satu teknologi yang berkembang dengan sangat cepat.mulai dengan berkembangnya pemanfaatan teknologi VoIP (Voice over Intenet Protocol), teknologi satelit yang memungkinkan melakukan komunikasi dimana saja, kapan saja, dan oleh siapa saja. Teknologi telekomunikasi bergerak (mobile technology) juga mengalami perkembangan yang sangat cepat dimulai dengan layanan $1 \mathrm{G}$ sampai dengan $4 \mathrm{G}$ dan bahkan $5 \mathrm{G}$. Untuk dapat meng-implementasikan pelacakan lokasi perlu diintegrasikan dua teknologi di atas, yaitu teknologi komunikasi GSM/CDMA yang sudah mengimplementasikan teknologi $3 \mathrm{G} / 4 \mathrm{G}$ dan teknologi penentuan posisi dengan GPS. Kedua teknologi tersebut perlu diintegrasikan karena mempunyai karakteristik masing-masing.

Pada google map terdapat teknologi pelacakan lokasi yaitu tracking, teknologi ini menggunakan GPS (Global Positioning System) sebagai sistem radio navigasi dan penentuan posisi secara real time disegala cuaca dengan tingkat ketelitian yang baik. Sampai saat ini GPS merupakan alat penentuan posisi yang paling populer di dunia tanpa dikenakan biaya pemakaian. Untuk dapat mengetahui posisi seseorang maka diperlukan alat yang bernama GPS receiver yang berfungsi untuk menerima sinyal dari satelit GPS. GPS reciever mempunyai karakteristik dapat menghasilkan informasi data posisi tetapi tidak dapat mengirimkan data tersebut dengan jarak jauh. Sedangkan 3G/4G sebagai teknologi komunikasi wireless dapat mengirimkan data dengan jangkauan yang luas dan kapasitas data yang besar serta dapat di aplikasikan secara mobile[7].

Berdasarkan latar belakang masalah tersebut, maka penelitian kali ini membahas suatu aplikasi berbasis mobile Android, dan diberi nama "MANDOSE" yang akan menyelesaikan masalah tersebut. Tujuan penelitian adalah memanfaatkan fitur tracking atau pelacakan lokasi dengan memanfaatkan GPS , Google Map dan teknologi komunikasi GSM/CDMA. Sehingga mahasiswa tidak lagi disulitkan dalam mencari dosen untuk urusan tertentu. Dengan memanfaatkan perangkat android yang terintegrasi dengan GPS, serta layanan dari Google Map.

\section{B. Tinjauan Pustaka}

1) Pada penelitian sebelumnya, ada beberapa penelitian mengenai aplikasi android, antara lain pada penelitian [1] [7] [8] [9] [10]. Dan peneilitan fokus pada GPS antara lain pada penelitian [1] [7] [8].

2) GPS (Global Positioning System)

GPS adalah sistem navigasi untuk penentuan posisi dengan menggunakan satelit yang dimiliki dan dikelola oleh Amerika Serikat. Nama formalnya adalah NAVSTAR GPS, kependekan dari "Navigation Satellite Timing and Ranging Global Positioning System". Dalam penentuan posisi GPS mengacu pada datum global yang disebut WGS 1984 sehingga semua GPS mengacu pada datum yang sama. Sistem koordinat WGS 1984 mengacu pada sistem koordinat kartesia terikat bumi dimana sumbu-X dan sumbu-Y tegak lurus terhadap sumbu-X [1].

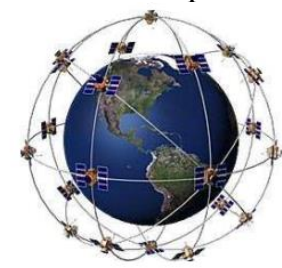

Gambar 1. Sistem Satelit GPS

(simber: kajianpustaka.com)

\section{3) Sistem Koordinat Geografis dan Posisi}

Sistem koordinat adalah metode numeric untuk merepresentasikan lokasi pada permukaan bumi. Sebagain besar biasanya menggunakan derajat latitude dan longitude yang di ekpresikan dalam bentuk degree, minutes dan seconds. Latitude (Lat) adalah sudut antara titik dan garis equator. Equator adalah garis imaginer yang membelah permukaan bumi menjadi dua bagian yaitu utara dan selatan. Garis Equator adalah letak $0^{\circ}$ latitude. Latitude bernilai dari $0^{\circ}$ di equator sampai $90^{\circ} \mathrm{N}$ atau $90^{\circ} \mathrm{S}$ ke kutub [1]. Longitude (Long) adalah sudut yang diukur dari titik arbitrasi (The Royal Observatory, Greenwich (UK)) sekaligus menjadi titik nol longitude (longitude $=0^{\circ}$ ). Nilai longitude dari $0^{\circ}$ sampai $180^{\circ} \mathrm{W}$ atau $180^{\circ}$ E. Dengan mengkombinasikan dua sudut (longitude dan latitude) tersebut, maka posisi di bumi dapat di ketahui dengan spesifik. Latitude diukur dari equator, dengan nilai positif jika di sebelah utara equator dan negatif jika disebelah selatan equator. Longitude diukur dari Prime Meridian (Greenwich), dengan nilai positif jika berada di sebelah timur dan negatif jika disebelah barat Greenwich [1]. 


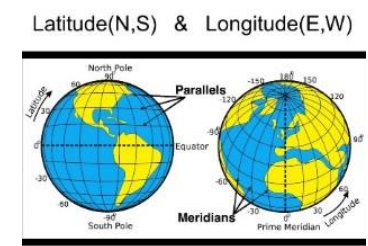

Gambar 2. Sistem Koordinat Bumi

(sumber:gurugeografi.id)

\section{4) Android dan GPS}

Dewasa ini, teknologi berkembang dengan pesat. Dulu ponsel hanya sekedar digunakan untuk menelpon dan SMS saja. Sekarang ponsel sudah menjelma menjadi kotak kecil ajaib yang serba bisa. Dengan standarisasi fitur dan hardware yang dimiliki, menjadikan ponsel Android ponsel canggih yang disukai banyak orang. Tidak lagi canggih karena adanya fitur MMS, radio, atau internet berkecepatan tinggi tapi juga karena ditanamkannya fitur teknologi satelit di dalamnya. Dengan ponsel berteknologi satelit (GPS), banyak hal yang bisa dilakukan. Ingin melihat di mana posisi user sekarang dalam sebuah peta, Mengambil foto/video yang sudah dilengkapi dengan data koordinat,dan lainnya. Semua itu bisa dilakukan dengan ponsel Android yang memiliki fitur GPS.

\section{5) Metode A-GPS (Assisted-Global Positioning System)}

AGPS juga merupakan metode yang berbasis pada waktu. Pada metode ini, akan dilakukan pengukuran waktu tiba dari sebuah sinyal yang dikirim dari tiga buah satelit GPS. Hal ini berarti handset harus memiliki fasilitas untuk mengakses GPS. A-GPS juga menghasilkan akurasi secara vertikal dan estimasi jarak yang baik. Akurasinya pun sampai kurang dari $10 \mathrm{~m}$.

\section{Pembahasan}

\section{A. Metode Penelitian}

Kerangka pemikiran merupakan gambaran umum dari rangkaian proses yang dilakukan dalam suatu penelitian. Gambar 3 adalah kerangka Pemikiran dari penelitian ini.

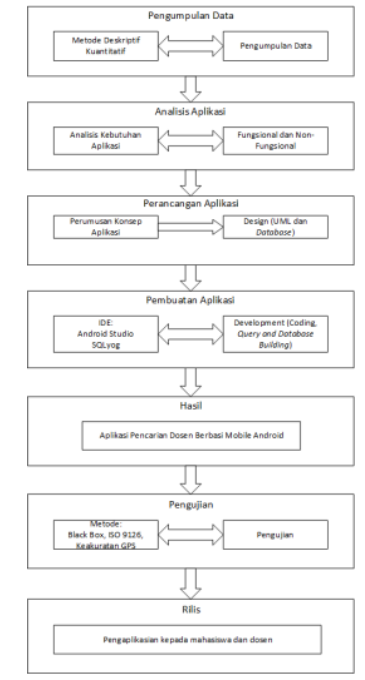

Gambar 3. Kerangka Pemikiran

\section{B. Metode Pengumpulan Data}

Penyusun menggunakan kuesioner atau angket dalam mengumpulkan data yang didalamnya terdapat seperangkat daftar pertanyaan yang telah disusun sebelumnya. Pengumpulaan data dilakukan dengan menggunakan alat ukur berupa lembar kuesioner berskala Guttman, data yang diperoleh berupa data interval atau rasio dikotomi (dua alternatif) yaitu "Ya" dan "Tidak" sehingga dengan demikian penyusun berharap mendapatkan jawaban yang tegas terhadap suatu permasalahan yang diteliti. Adapun tahapan proses pengumpulan data dalam penelitian ini yaitu:

1. Pengambilan data dilakukan oleh penyusun sendiri dengan mendatangi subjek penelitian.

2. Penyusun menjelaskan kepada calon responden mengenai teknik pengisian kuesioner dan apabila ada suatu yang kurang jelas, calon responden dipersilahkan untuk bertanya.

3. Pengumpulan data dilakukan dengan cara membagikan kuesioner secara langsung maupun secara online oleh penyusun dibantu oleh rekanrekan penyusun, dan setelah pengisian selesai, kuesioner dikumpulkan kepada penyusun.

4. Data primer didapat dari hasil pengisiankuesioner yang berisi data mengenai pemasalahan yang diberikan.

\section{Konsep Dasar Aplikasi}

Aplikasi yang akan dibangun dalam penelitian ini dinamakan "Aplikasi MANDOSE". Ide dasar dari aplikasi ini yaitu bagaimana caranya mengetahui lokasi dosen dengan mudah melalui smartphone, sehingga mahasiswa tidak perlu lagi berlama-lama menunggu atau kebingungan dalam mencari dosen.

Aplikasi ini mempunyai 2 fitur inti yaitu "Real Time Location" dan "Fixed Location". "Real Time Location" cara kerjanya yaitu men-trace lokasi dosen, selanjutnya didapatkan koordinat lokasi berupa longitude dan latitude yang akan di upload kedalam database, koordinat tersebut akan selalu diupdate dalam rentang waktu yang ditentukan, atau dengan "Fixed Location" cara kerjanya yaitu meng-upload lokasi ke-dalam database berupa longitude dan latitude yang sudah ditetapkan dan berada di dalam aplikasi.

D. Use Case Diagram Sistem

Use Case diagram menggambarkan fungsionalitas yang diharapkan dari sebuah sistem. Usecase diagram pada level dosen dan mahasiswa dapat dilihat pada gambar berikut: 


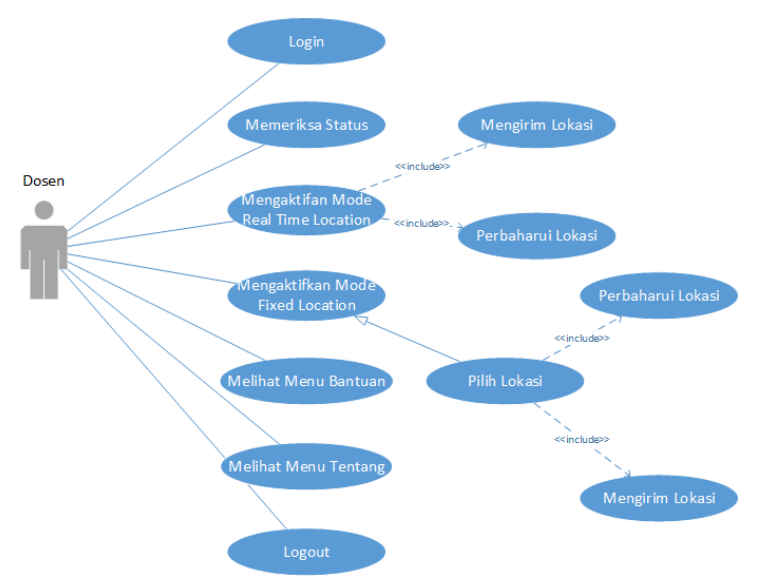

Gambar 4. Use Case Diagram Level Dosen

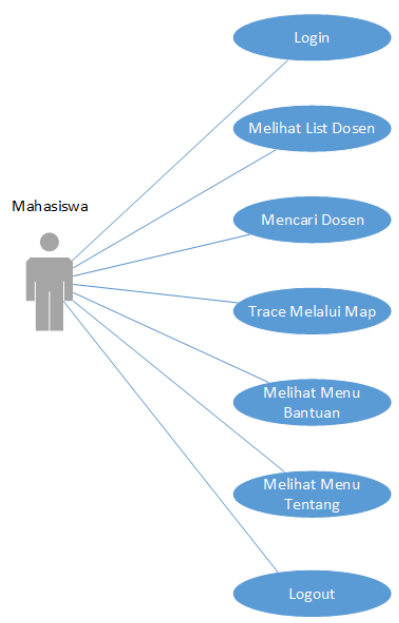

Gambar 5. Use Case Diagram Level Mahasiswa

\section{Implementasi dan Hasil}

\section{1) Hasil Aplikasi yang telah dibuat}

\section{A Tampilan Splashscreen}

Tampilan splash screen adalah tampilan awal saat pengguna membuka aplikasi, terdapat progresbar dan background gambar. Tampilan splash screen dapat dilihat pada gambar 6 berikut.

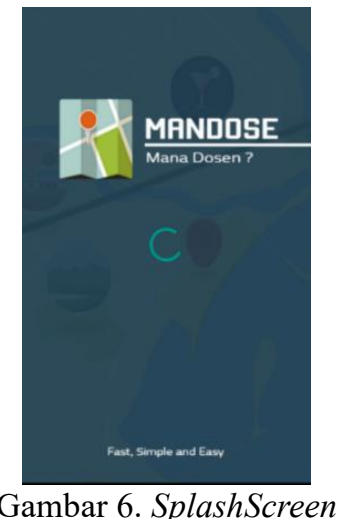

\section{B Tampilan Login}

Tampilan Login berada pada LoginActivity, pada tampilan ini pengguna harus memasukan username, password, dan level yang sudah terdaftar di dalam database untuk dapat mengakses aplikasi secara penuh. Tampilan login dapat dilihat pada gambar 7 berikut.

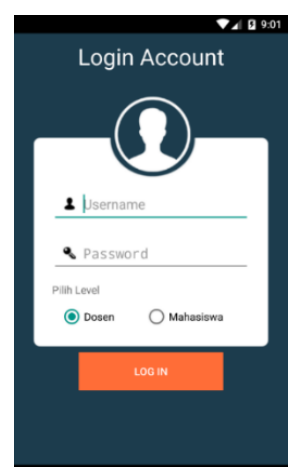

Gambar 7. Login

\section{Tampilan Status Online (Dosen)}

Tampilan status online terdapat pada DosenActivity. Pada tampilan ini aplikasi memberikan infromasi kepada pengguna bahwa pengguna sedang dalam status offline dan dapat di trace keberadaanya. Tampilan status online dapat dilihat pada gambar 8 berikut.

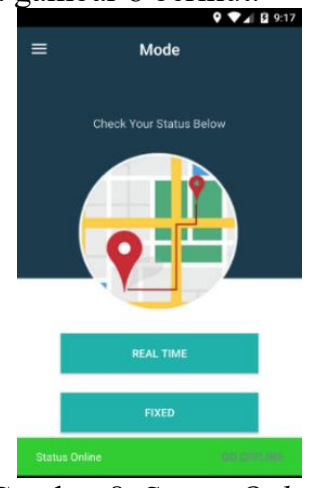

Gambar 8. Status Online

\section{Tampilan Status Offline (Dosen)}

Tampilan status offline terdapat pada DosenActivity. Pada tampilan ini aplikasi memberikan infromasi kepada pengguna bahwa pengguna sedang dalam status offline. Tampilan status offline dapat dilihat pada gambar 9 berikut.

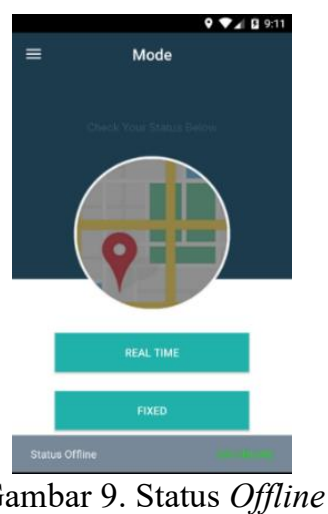

Pada tampilan gambar 9 terdapat beberapa komponen: Icon panel navgiasi berupa strip 3 yang terdapat di toolbar untuk membuka panel navigasi, tombol dengan latar 
gambar map untuk pengecekan status, tombol REAL TIME untuk pemilihan mode, dan tombol FIXED untuk mengakses FixedLocationActivity.

\section{E Tampilan Fixed Location}

Tampilan fixed location adalah tampilan untuk menampilkan list berupa data lokasi yang sudah disediakan oleh aplikasi, data lokasi yang ada langsung request kedalam database server. Pengguna dapat mengakses tampilan ini melalui tombol FIXED yang berada pada DosenActivity atau melalui panel navigasi. Tampilan fixed location membutuhkan koneksi internet. Tampilan fixed location dapat dilihat pada gambar 10 berikut.

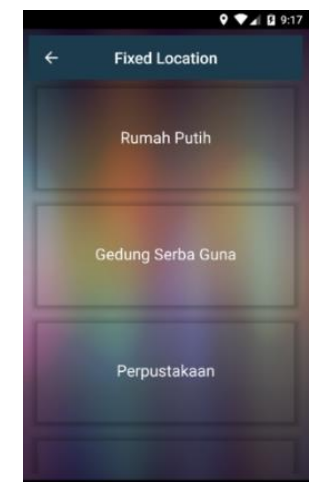

Gambar 10. Fixed Location

Pada tampilan gambar 10 terdapat beberapa komponen serta URL yang digunakan untuk request dan getRequest data: Tombol kembali berupa icon panah yang terdapat pada toolbar berguna untuk kembali ke DosenActivity, list berupa card view berisi data lokasi, jika dipilih berguna untuk mengaktifkan mode Fixed Location.

\section{F Tampilan List Dosen Online (Mahasiswa)}

Tampilan list dosen menampilkan data berupa list dosen yang online atau dapat dilacak lokasinya. Tampilan list dosen membutuhkan koneksi internet. Tampilan list dosen dapat dilihat pada gambar 11 berikut.

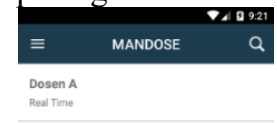

\section{Gambar 11. List Dosen Online}

\section{G Tampilan Maps Digital}

Tampilan maps menampilkan maps digital dengan point berupa pin lokasi sesuai koordinat dari data dosen yang berstatus online. Tampilan ini membutuhkan koneksi internet untuk load maps dari server Google. Tampilan maps dapat dilihat pada gambar 12 berikut.

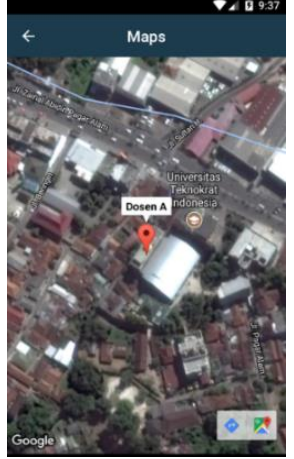

Gambar 12. Maps Digital

\section{2) Hasil Pengujian ISO 9126}

Dalam pengujian pada penelitian ini menggunakan balckbox dan ISO 9126. Penggunaan ISO 9126, ada beberapa aspek yang diujikan antara lain Reliability, Usability, Efficiency dan Portability.

\section{a. Aspek Reliability}

Pada tabel 1, adalah hasil pengujian dari aspek Reliability. Tabel 1 Hasil pengujian Reliability

\begin{tabular}{|c|c|c|c|c|c|c|}
\hline \multirow{3}{*}{$\begin{array}{l}\text { Kriteria } \\
\text { Jawaban }\end{array}$} & \multirow{3}{*}{ Bobot } & \multicolumn{5}{|c|}{ Reliability } \\
\hline & & $\begin{array}{l}\text { Matu } \\
\text { rity }\end{array}$ & $\begin{array}{l}\text { to } \\
\text { ce }\end{array}$ & & & $\begin{array}{l}\text { ve } \\
\text { lity }\end{array}$ \\
\hline & & 12 & 3 & 4 & 5 & 6 \\
\hline
\end{tabular}

\begin{tabular}{lllllllll}
\hline $\begin{array}{l}\text { Sangat } \\
\text { Setuju }\end{array}$ & $\mathbf{5}$ & 6 & 5 & 4 & 3 & 5 & 5 & \\
\hline Setuju & $\mathbf{4}$ & 4 & 5 & 6 & 7 & 5 & 5 & \\
\hline Ragu-ragu & $\mathbf{3}$ & & & & & & & \\
\hline $\begin{array}{l}\text { Tidak } \\
\text { Setuju }\end{array}$ & $\mathbf{2}$ & & & & & & & \\
\hline $\begin{array}{l}\text { Sangat } \\
\text { Tidak }\end{array}$ & $\mathbf{1}$ & & & & & & & \\
Setuju & & 1 & 1 & 10 & 10 & 10 & 10 & \\
\hline Jumlah Responden & 0 & 0 & & & & & & \\
\hline Skor Aktual & & 4 & 4 & 44 & 43 & 45 & 45 & 269 \\
\hline Skor Ideal & 5 & 5 & 5 & 50 & 50 & 50 & 50 & 300 \\
& 0 & 0 & & & &
\end{tabular}

$\%$ Skor Aktual $=\frac{\text { Skor Aktual }}{\text { Skor Ideal }} \times 100 \%$

$$
=\frac{268}{250} \times 100 \%=89.3 \%(\text { kriteria Baik })
$$

\section{b. Aspek Usability}

Pada pengujian usability, dengan cara membagikan kuisioner kepada pengguan sistem. Pengujan dilakukan untuk mendapatkan penilaian dari pengguna, apakah sistem dapat diterima. Pada tabel 2, adalah hasil pengujian dari aspek Usability.

Tabel 2. Hasil Pengujian Usability 


\begin{tabular}{|c|c|c|c|c|c|c|c|c|c|c|c|c|c|}
\hline \multirow{3}{*}{ KJ } & \multirow{3}{*}{ B } & \multicolumn{11}{|c|}{ Usability } & \multirow{3}{*}{ Tot } \\
\hline & & \multicolumn{3}{|c|}{$\mathrm{U}$} & \multicolumn{2}{|c|}{$\mathrm{L}$} & \multicolumn{3}{|c|}{$\mathrm{O}$} & \multicolumn{3}{|c|}{ A } & \\
\hline & & 7 & 8 & 9 & 10 & 11 & 12 & 13 & 14 & 15 & 16 & 17 & \\
\hline SS & 5 & 6 & 6 & 4 & 7 & 7 & 5 & 4 & 3 & 6 & 2 & 5 & \\
\hline $\mathrm{S}$ & 4 & 4 & 4 & 6 & 3 & 3 & 5 & 6 & 7 & 4 & 8 & 5 & \\
\hline $\mathrm{R}$ & 3 & & & & & & & & & & & & \\
\hline TS & 2 & & & & & & & & & & & & \\
\hline STS & 1 & & & & & & & & & & & & \\
\hline $\mathrm{JF}$ & & 10 & 10 & 10 & 10 & 10 & 10 & 10 & 10 & 10 & 10 & 10 & \\
\hline $\mathbf{S}_{A}$ & & 46 & 46 & 44 & 47 & 47 & 45 & 44 & 43 & 46 & 42 & 45 & 495 \\
\hline S. & & 50 & 50 & 50 & 50 & 50 & 50 & 50 & 50 & 50 & 50 & 50 & 550 \\
\hline
\end{tabular}

$\%$ Skor Aktual $=\frac{\text { Skor Aktual }}{\text { Skor Ideal }} \times 100 \%$

$$
=\frac{495}{550} \times 100 \%=90 \%(\text { kriteria Sangat Baik) }
$$

\section{Aspek Efficiency}

Pada tabel 3, adalah hasil pengujian dari aspek Effiency. Tabel 3 Hasil Pengujian Efficiency

\begin{tabular}{|c|c|c|c|c|c|}
\hline \multirow{3}{*}{$\begin{array}{l}\text { Kriteria } \\
\text { Jawaban }\end{array}$} & \multirow{3}{*}{ Bobot } & \multicolumn{3}{|c|}{ Efficiency } & \multirow{3}{*}{ Total } \\
\hline & & \multicolumn{2}{|c|}{$\begin{array}{l}\text { Time } \\
\text { behaviour }\end{array}$} & \multirow{2}{*}{$\begin{array}{l}\text { Resource } \\
\text { behaviour } \\
\mathbf{2 0}\end{array}$} & \\
\hline & & 18 & 19 & & \\
\hline $\begin{array}{l}\text { Sangat } \\
\text { Setuju }\end{array}$ & 5 & 4 & 7 & 3 & \\
\hline Setuju & 4 & 6 & 3 & 4 & \\
\hline Ragu-ragu & 3 & & & 3 & \\
\hline $\begin{array}{l}\text { Tidak } \\
\text { Setuju }\end{array}$ & 2 & & & & \\
\hline $\begin{array}{l}\text { Sangat } \\
\text { Tidak } \\
\text { Setuju }\end{array}$ & 1 & & & & \\
\hline \multicolumn{2}{|c|}{ Jumlah Responden } & 10 & 10 & 10 & \\
\hline \multicolumn{2}{|c|}{ Skor Aktual } & 44 & 47 & 40 & 131 \\
\hline \multicolumn{2}{|l|}{ Skor Ideal } & 50 & 50 & 50 & 150 \\
\hline
\end{tabular}

\section{Pengujian Portability \\ 4.1 Ragam Perangkat}

Tabel 3. Hasil Pengujian Portability pada Perangkat yang berbeda.

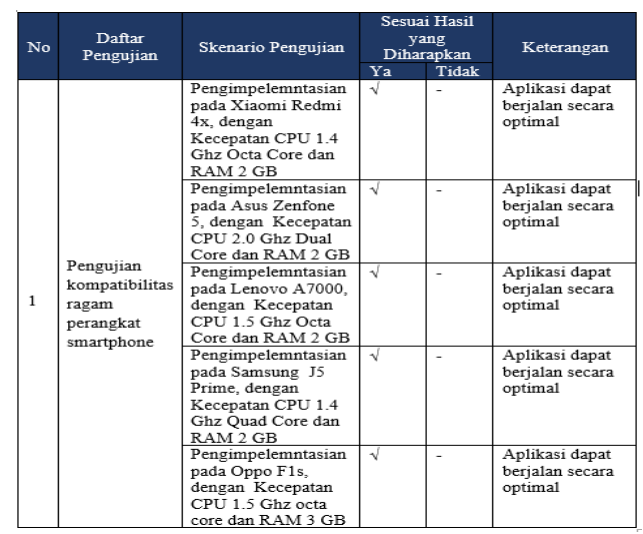

\subsection{Ragam Operating Sistem}

Tabel 4. Hasil Pengujian Portability pada Sistem Operasi yang berbeda.

\begin{tabular}{|c|c|c|c|c|c|}
\hline \multirow[t]{2}{*}{ No } & \multirow[t]{2}{*}{$\begin{array}{c}\text { Daftar } \\
\text { pengujian }\end{array}$} & \multirow[t]{2}{*}{ Skenario Pengujian } & \multicolumn{2}{|c|}{$\begin{array}{l}\text { Sesuai Hasil } \\
\text { yang } \\
\text { Diharapkan }\end{array}$} & \multirow[t]{2}{*}{ Keterangan } \\
\hline & & & Ya & Tidak & \\
\hline \multirow{5}{*}{1} & \multirow{5}{*}{$\begin{array}{l}\text { Pengujian } \\
\text { kompatibilitas } \\
\text { versi } \\
\text { operating } \\
\text { system } \\
\text { Android }\end{array}$} & $\begin{array}{l}\text { Penginstalan aplikasi } \\
\text { pada Android versi } \\
4.4 .4 \text { (Kitkat) }\end{array}$ & - & $\sqrt{ }$ & $\begin{array}{l}\text { Terjadi } \\
\text { kesalahan } \\
\text { ekstrasi data } \\
\text { saat } \\
\text { penginstalan }\end{array}$ \\
\hline & & $\begin{array}{l}\text { Penginstalan aplikasi } \\
\text { pada Android versi } \\
5.0 \text { (Lollipop) }\end{array}$ & $\sqrt{ }$ & - & $\begin{array}{l}\text { Penginstalan } \\
\text { sukses dan } \\
\text { aplikasi dapat } \\
\text { dijalankan }\end{array}$ \\
\hline & & $\begin{array}{l}\text { Penginstalan aplikasi } \\
\text { pada Android versi } \\
6.0 \text { (Marshmallow) }\end{array}$ & $\sqrt{ }$ & - & $\begin{array}{l}\text { Penginstalan } \\
\text { sukses dan } \\
\text { aplikasi dapat } \\
\text { dijalankan }\end{array}$ \\
\hline & & $\begin{array}{l}\text { Penginstalan aplikasi } \\
\text { pada Android versi } \\
7.0 \text { (Nougat) }\end{array}$ & $\sqrt{ }$ & - & $\begin{array}{l}\text { Penginstalan } \\
\text { sukses dan } \\
\text { aplikasi dapat } \\
\text { dijalankan }\end{array}$ \\
\hline & & $\begin{array}{l}\text { Penginstalan aplikasi } \\
\text { pada Android versi } \\
8.0 \text { (Oreo) }\end{array}$ & $\sqrt{ }$ & - & $\begin{array}{l}\text { Penginstalan } \\
\text { sukses dan } \\
\text { aplikasi dapat } \\
\text { dijalankan }\end{array}$ \\
\hline
\end{tabular}

\subsection{Ragam Ukuran Layar}

Tabel 5. Hasil Pengujian Portability pada Sistem Operasi yang berbeda

\begin{tabular}{|c|c|c|c|c|c|}
\hline \multirow[t]{2}{*}{ No } & \multirow[t]{2}{*}{$\begin{array}{c}\text { Daftar } \\
\text { Pengujian }\end{array}$} & \multirow[t]{2}{*}{ Skenario Pengujian } & \multicolumn{2}{|c|}{$\begin{array}{c}\text { Sesuai Hasil } \\
\text { yang } \\
\text { Diharapkan }\end{array}$} & \multirow[t]{2}{*}{ Keterangan } \\
\hline & & & $\mathrm{Ya}$ & Tidak & \\
\hline \multirow{3}{*}{1} & \multirow{3}{*}{$\begin{array}{l}\text { Pengujian } \\
\text { Resolusi } \\
\text { Layar dan } \\
\text { Densistas } \\
\text { Layar pada } \\
\text { Android }\end{array}$} & $\begin{array}{l}\text { Penginstalan pada } \\
\text { Android dengan } \\
\text { Layar Resolusi } 4 \\
\text { inch }\end{array}$ & $\sqrt{ }$ & - & $\begin{array}{l}\text { Tampilan } \\
\text { terlihat sesuai } \\
\text { dan baik serta } \\
\text { dapat } \\
\text { dioperasikan } \\
\text { dengan baik }\end{array}$ \\
\hline & & $\begin{array}{l}\text { Penginstalan pada } \\
\text { Android dengan } \\
\text { Layar Resolusi } 5 \\
\text { inch }\end{array}$ & $\sqrt{ }$ & - & $\begin{array}{l}\text { Tampilan } \\
\text { terlihat sesuai } \\
\text { dan baik serta } \\
\text { dapat } \\
\text { dioperasikan } \\
\text { dengan baik }\end{array}$ \\
\hline & & $\begin{array}{l}\text { Penginstalan pada } \\
\text { Android dengan } \\
\text { Layar Resolusi } 6 \\
\text { inch }\end{array}$ & - & $\sqrt{ }$ & $\begin{array}{l}\text { Tampilan } \\
\text { kurang baik, } \\
\text { dikarenakan } \\
\text { gambar latar } \\
\text { melebar, tetapi } \\
\text { tetap dapat } \\
\text { dioperasikan } \\
\text { dengan baik }\end{array}$ \\
\hline
\end{tabular}

Aplikasi lolos dalam uji fungsional blackbox dengan menggunakan metode equivalence partitioning, fungsi dapat berjalan $100 \%$ dengan minimal versi operating sistem android 5.0 (Lollipop). Aplikasi lolos dalam uji kualitas standar ISO 9126 dengan nilai aspek reliability (89.3\%), aspek usability (90\%), aspek efficiency (87.3\%), dan aspek portability aplikasi dapat berjalan secara optimal diberbagai macam perangkat serta lolos dalam uji keakuratan GPS dengan hasil koordinat yang dihasilkan mendekati koordinat yang diharapkan. Secara umum aplikasi ini dapat diterima dan berjalan dengan baik.

\section{Kesimpulan}

Berdasarkan hasil penelitian dan pembahasan yang telah dilakukan, dapat disimpulkan bahwa:

Aplikasi MANDOSE merupakan aplikasi native 
berbasis mobile platform android yang dirancang menggunakan Java dan JSON sebagai pemograman logic, XML sebagai pemograman interface, PHP sebagai pemograman server-side scripting, dan MySql sebagai database. Aplikasi ini memiliki fitur untuk melacak keberadaan perangkat (dosen) dan dipresentasikan ke dalam map digital. Pada pengujian fungsional menggunakan black box, fungsi dapat berjalan 100\% dengan minimal versi operating sistem android 5.0 (Lollipop) membuktikan sistem pelacakan lokasi dengan GPS dan Google Maps dapat diimplementasikan ke dalam aplikasi pencarian device.

Pengujian dalam aspek reliability tingkat persetujuan pengguna sebesar 89,3\% dengan kategori baik, dalam aspek usability tingkat persetujuan pengguna sebesar $90 \%$ dengan kategori sangat baik membuktikan sistem yang dibuat dapat memudahkan mahasiswa yang bersangkutan dalam menyelesaikan masalah, dalam aspek efficiency tingkat persetujuan pengguna sebesar $87.3 \%$ dengan kategori baik. Pengujian dalam aspek portability aplikasi dapat berjalan optimal diberbagai macam perangkat yang diujicobakaan tanpa error, membuktikan sistem yang dibuat dapat digunakan diberbagai macam perangkat smartphone android. Pada pengujian keakuratan GPS, koordinat yang dihasilkan GPS Receiver yang terdapat di berbagai perangkat smartphone android mendekati dari koordinat yang diharapkan.

\section{Daftar Pustaka}

[1] Abidin, H. Z., 2001, "Penetuan Posisi Dengan GPS Dan Aplikasinya, PT Pradnya Paramita”, Jakarta.
[2] Android, "Android History". https://www.android.com/history (diakses 27 September 2017)

[3] Allan. D. Et al., 2009. "Systems Analysis \& Design with UML Version 2.0". United States of America.

[4] Kustiyahningsih, Y. dan Anamisa, D. R., 2011, "Pemrograman Basis Data Berbasis Web Menggunakan PHP \& MySQL". Edisi Pertama. Graha Ilmu. Yogyakarta.

[5] Raharjo. B., 2011, "Membuat Database Menggunakan MySql". Informatika. Bandung

[6] Statcounter, "Mobile Vendor Market Share Worldwide".http://gs.statcounter.com/vendormarket-share/mobile (diakses 23 Mei 2017).

[7] Sunyoto, Andi, "Sistem Integrasi GPS Dan GSM Untuk Pendeteksian Posisi Dan Pergerakan Pada Obyek Bergerak", S2 Jurusan Ilmu Komputer UGM, 2003.

[8] Borman, R.I., Syahputra, K. and Prasetyawan, P., "Implementasi Internet Of Things pada Aplikasi Monitoring Kereta Api dengan Geolocation Information System". Prosiding Seminar Nasional Teknik Elektro. 2018.

[9] Lestari, I.D., Samsugi, S. and Abidin, Z. "Rancang Bangun Sistem Informasi Pekerjaan Part Time Berbasis Mobile Di Wilayah Bandar Lampung". TELEFORTECH: Journal of Telematics and Information Technology, Vol. 1(1). 2020.

[10] Harahap, A., Sucipto, A., Jupriyadi. "Pemanfaatan Augmented Reality (Ar) Pada Media Pembelajaran Pengenalan Komponen Elektronika Berbasis Android". Jurnal Ilmiah Infrastruktur Teknologi Informasi (JIITI),Vol. 1(1) p. 20. 2020. 